\title{
Strategies for organizing and improving urban space (Case study: from Mahbas intersection to Mission intersection, Ahmad Shah Baba Mineh town)
}

Parviz Akhtar Jahid, Hamid Reza Ameri Siahvi, Asadollah Movahedi

\begin{abstract}
:
The city is a place for human life, where all the components necessary for human life must be present in the city so that human beings can live physically and mentally in peace. The cities of Afghanistan, especially the residential town of Ahmad Shah Baba Mina, are facing many problems. The purpose of this research was to investigate the problems of this town and to provide suggestions for its improvement and organization. The method of this research is library, perception and field considerations. Targeted interviews were conducted with 12 people who were familiar with urban design and urban planning issues. The analysis was performed by SWOT technique and space arrangement. The research results show that this town is faced with challenges such as transportation problems, lack of proper sidewalks, lack of urban furniture, visual personality and identity issues, environmental challenges, lack of proper distribution of land uses, congestion in public spaces. And there are issues that have changed the physical appearance and public spaces. During this research, suggestions for setting up public transportation routes, setting up vendors and new neighborhoods for their activities, Create special bike lanes, Improving the quality of public spaces has been provided to create public activities, improve public spaces as well as promote sensory richness.
\end{abstract}

Keywords: Improving, organizing, urban spaces, public spaces, activities, riding and walking.

Citation: Parviz Akhtar, J., Hamid Reza, A. S., \& Asadollah, M. (2021). Strategies for organizing and improving urban space (Case study: From Mahbas intersection to Mission intersection, Ahmad Shah Baba Mineh town). Journal of Urban Planning and Architecture, 2(3), 36-48. 


\title{
راهكارهاى ساماندهى و بهسازى فضاى شهرى (مطالعه موردى: از جهمار راهى محبس الى جهار راهى ماموريت، شهرى الحمد شاه بابا مينه)
}

\author{
يرويز اختر جهيد "“*، حميد رضا عامرى سياهوى ‘، اسدالله موحدى \\ 1-ماستر طراحى شهرى دانشخاه بيام نور مركز كابل \\ r-دانشيار دانشگاه ييام نورمركز كابل \\ ب-استاد دييارتنمت طراحى شهرى دانشخاه بيام نور مركز كابل
}

جكيده

شهر محلى براى زندگى انسانها است كه مىبايست تمام مولفهاى كه براى امرار حيات و زيست انسانها لازم است در شهر

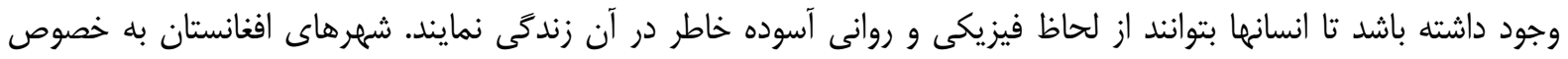

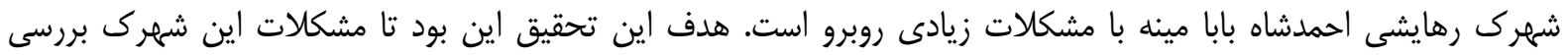

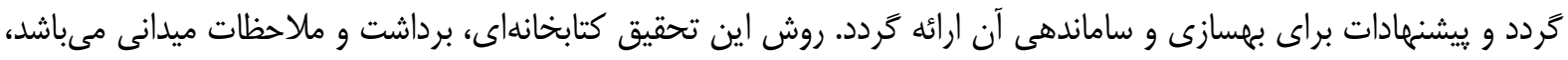

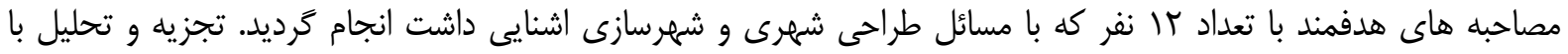

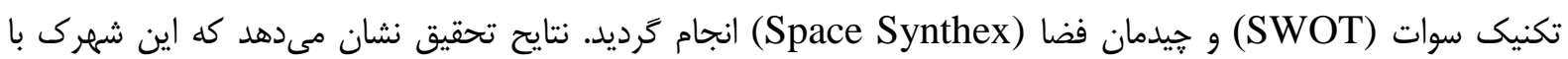

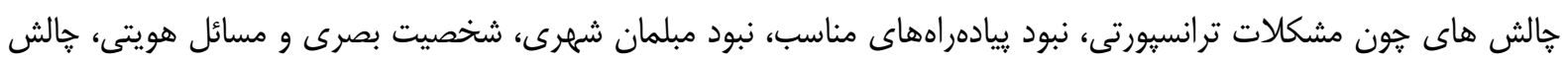

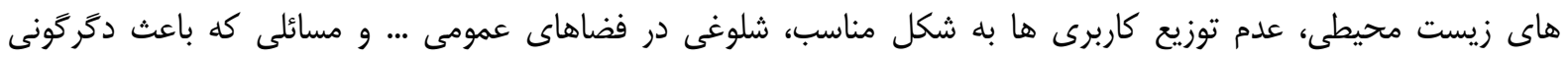

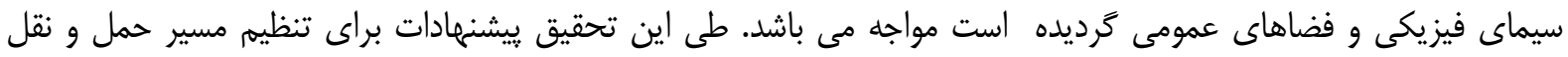

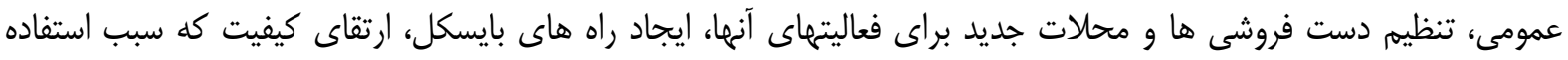

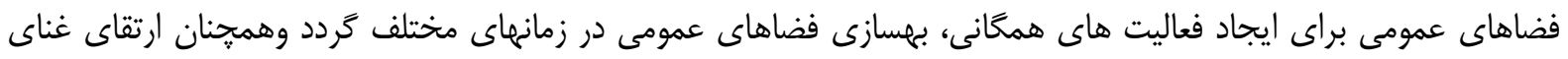
حسى ارائه گرديده است.

وازه هاى كليدى: بهسازى، ساماندهى، فضاهاى شهرى، فضاهاى عمومى، فعاليت ها، سواره و يياده.

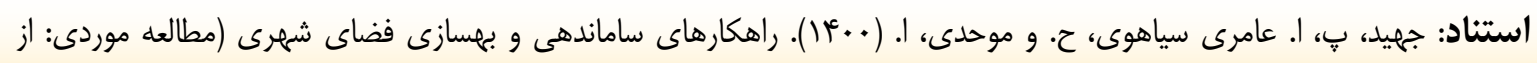

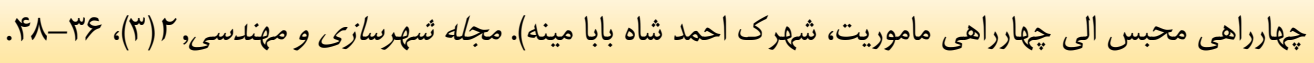

*pjaheed@gmail.com 


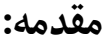

از اينكه شهر منحيث محيط مصنوع ساخت دست انسانها ميباشد لذا ضرورى است تا تمام عناصر تشكيل دهنده فضاهاى شهرى

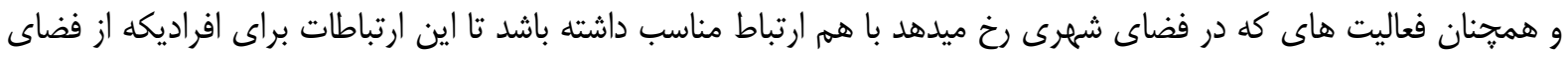
شهرى ديدن مينمايد و همجنان براى افراديكه در فضاهاى شهرى فعاليت مينمايد، داراى مفهومى باشد و داراى مولفه هاى هاى شهر

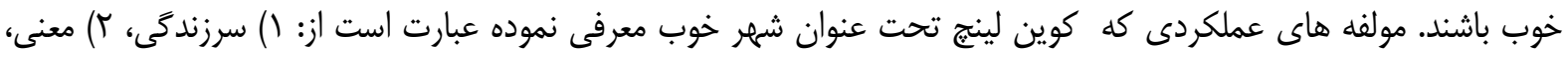

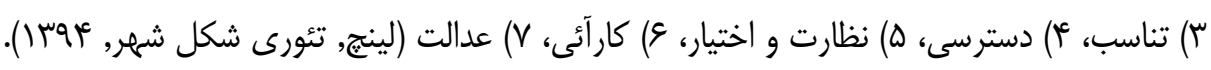

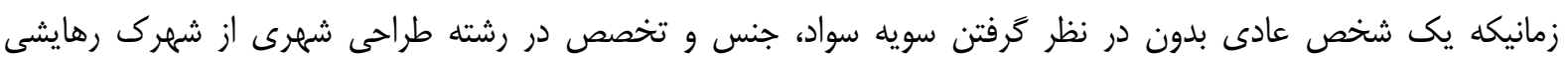

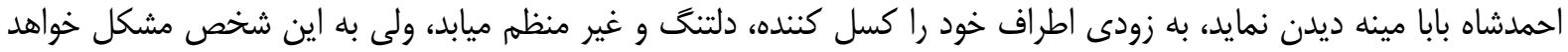

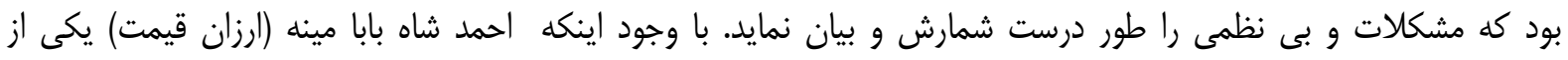

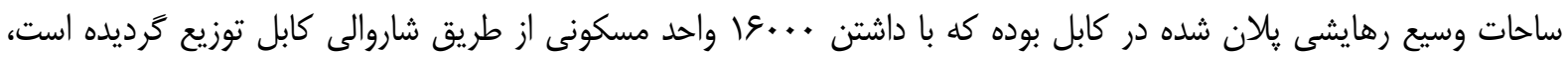

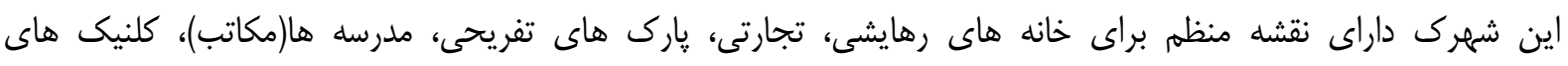

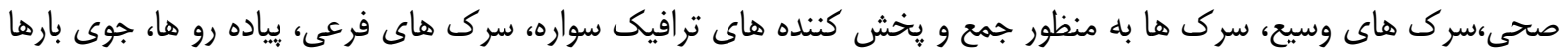

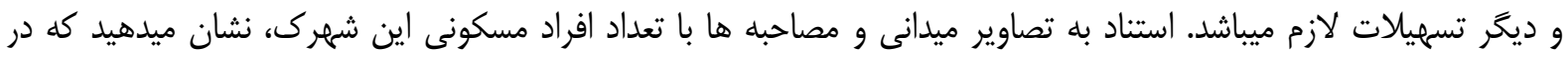

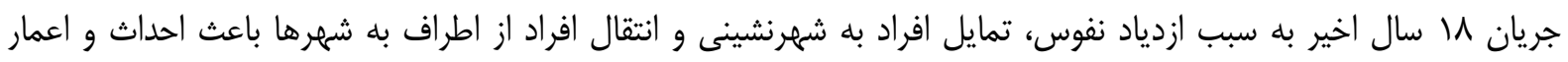

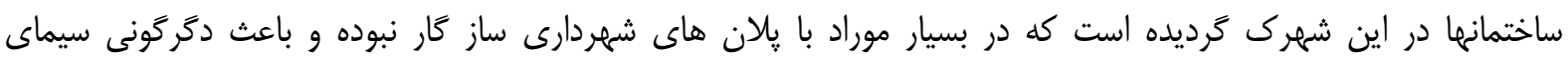

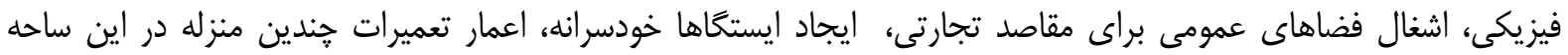
كرديده است. ميزان بلند بيكارى افراد جامعه و ضعف مديرت شاروالى (شهردارى) نيز باعث شده كه فضاهاى عمومى از طرف

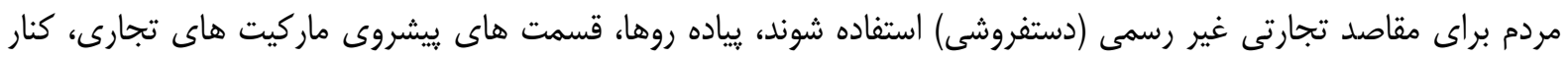

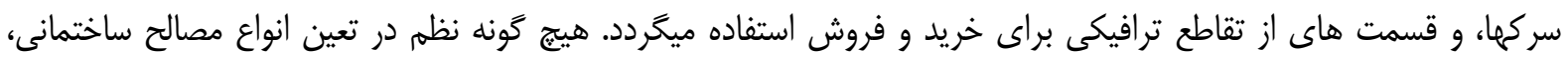

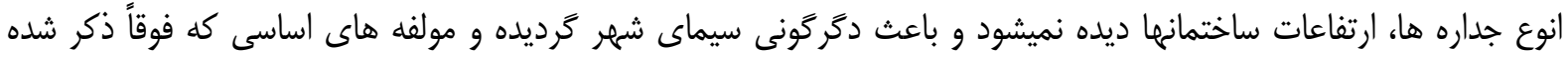
دخر گون گرديده است.

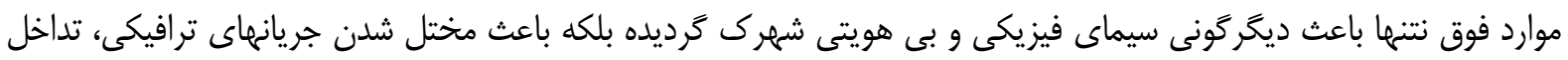

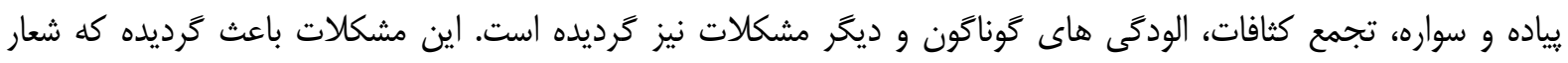

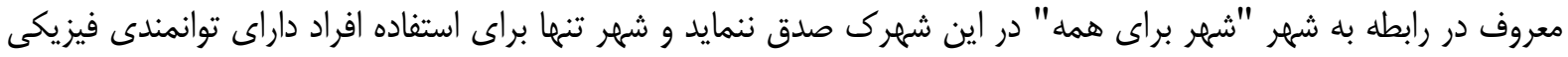

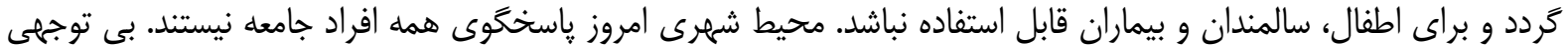

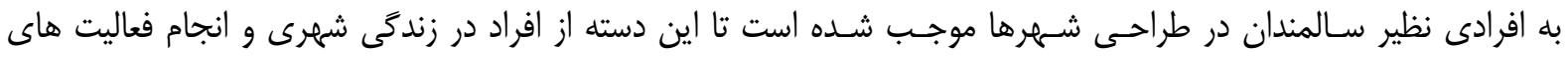

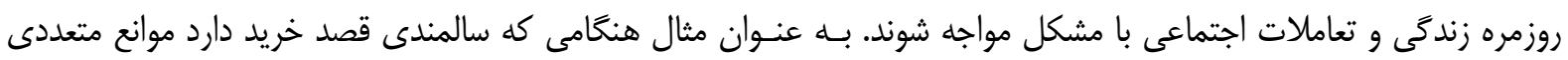
تصميم او را تغيير ميدهد. اختلاف سطوح متعدد، عدم وجود يل هاى مناسب، كفسازى هاى نامناسب، نبود مبلمان شهرى، حمل

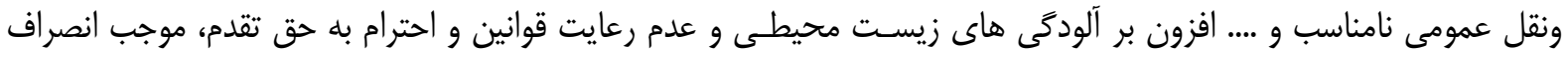

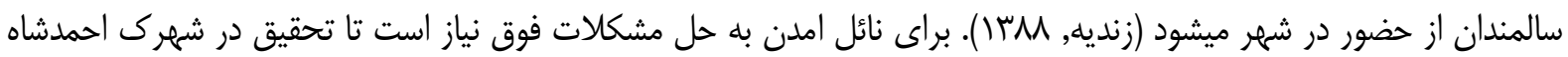

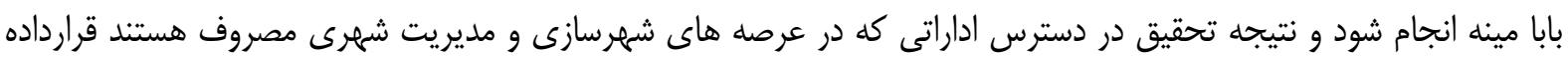

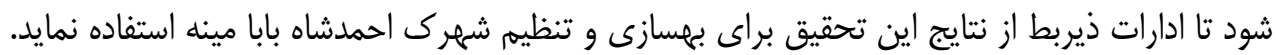
خلاصه مبانى نظرى: فضاهاى شهرى جز از كالبد شهرى بوده كه فعاليت هاى انسانها در آن اتفاق ميابند، به اين اساس

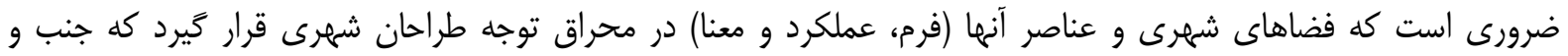

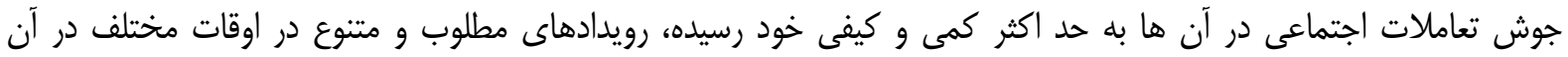
بوقوع بييوندد. 


\section{معرفى ساحه مورد مطالعه:}

شهرى احمدشاه بابا مينه واقع در شرق شهر كابل به فاصله 10 كيلومترى از مركز شهر كابل موقعيت دارد. اين شهرك در در ميان

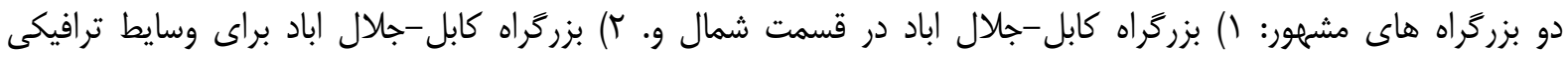

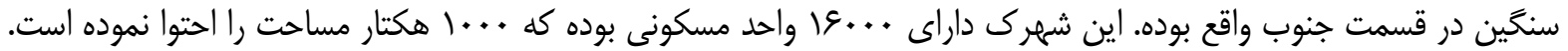

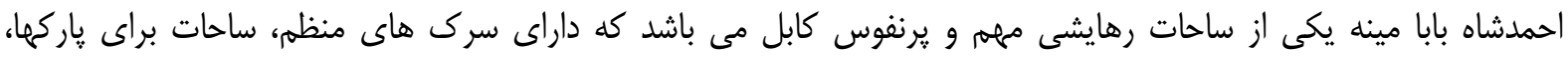

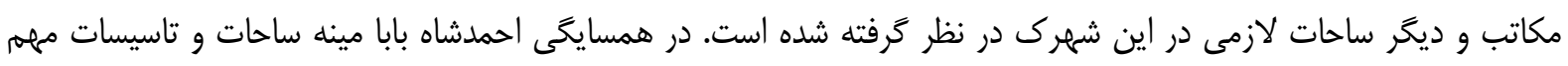

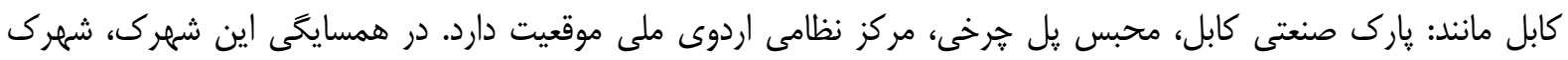
رهايشى سيد جمال الدين افغانى، شهرك نوروز آباد، شهرى رهايشى بتخاك، شهرك رهايشى باءرامى، ياركى تفريحى حبيب الله

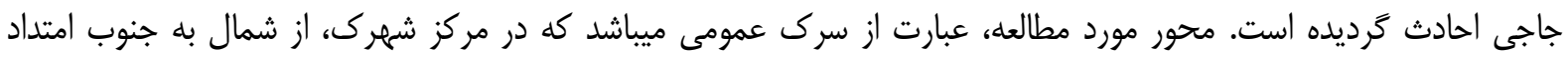

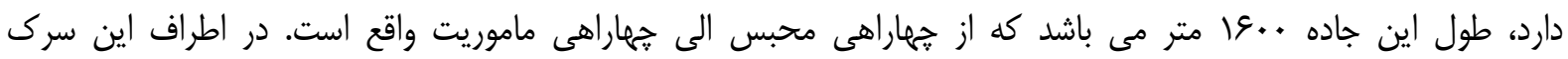

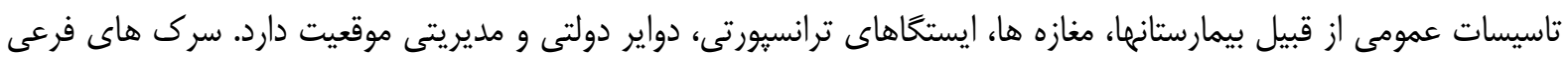

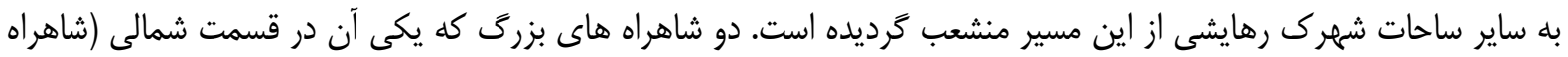

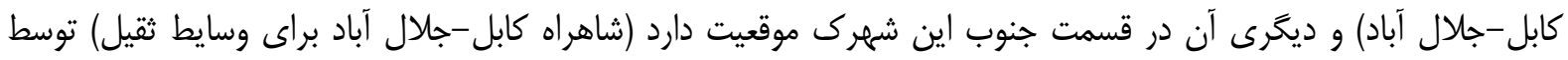

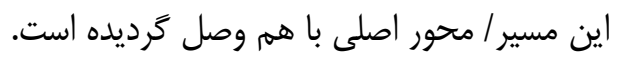

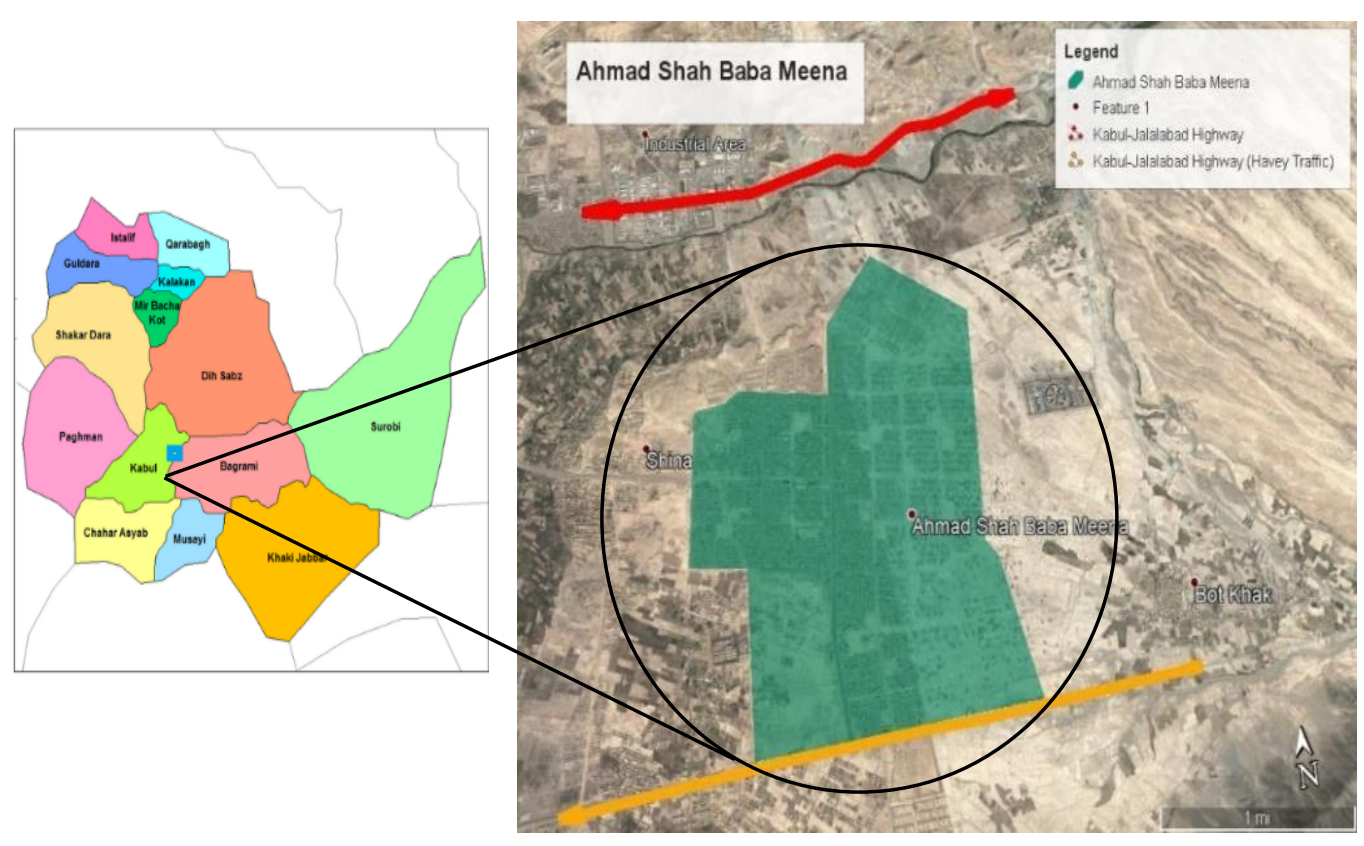

نقشه شماره ا: موقعيت احمدشاه بابا مينه در شهر كابل، منبع wikipedia

\section{روش تحقيق:}

روش اين تحقيق كتابخانه ى، برداشت و ملاحظات ميدانى ميباشد. كه مطالعات كتابخانه ى متشكل از اثر كتابهاى و مقالات

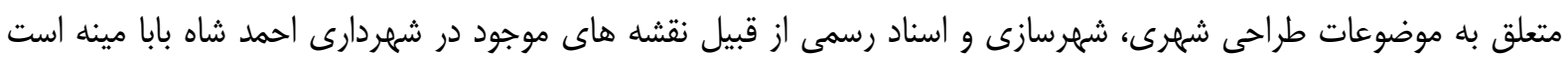

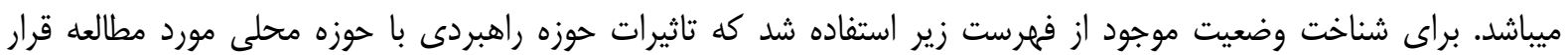




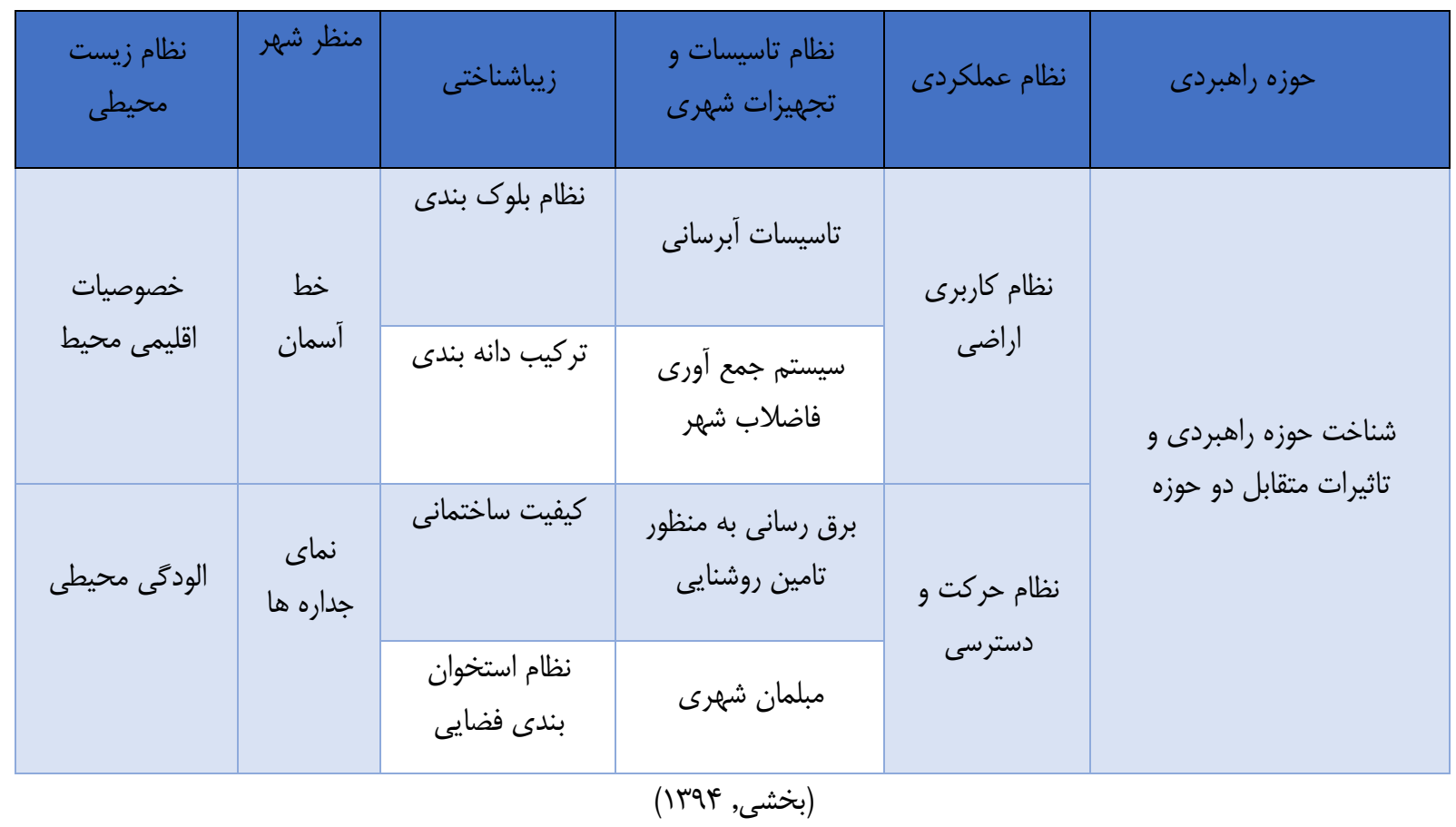

تحليل به دوه شيوه ذيل انجام يافت.

-تحليل جيدمان فضا:روش جيدمان فضا ارتباط كليئ فضاهاى شهرى را با يكديغر تجزيه و تحليل مى كند و نتايج را به صورت يارامترهاى رياضى و گرافيكى ارايه مى دهد. يارامترهاى رياضى مى توانند در ايجاد مدلى كه نحوه عملكرد و رفتار راد در

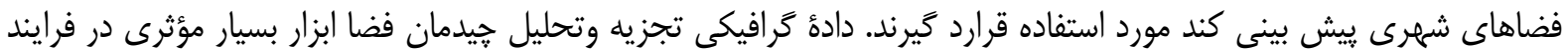

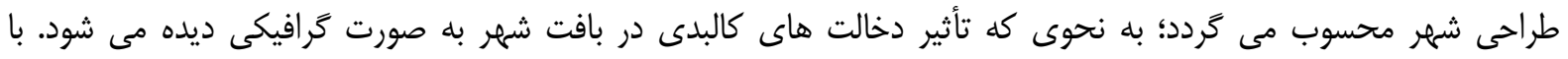

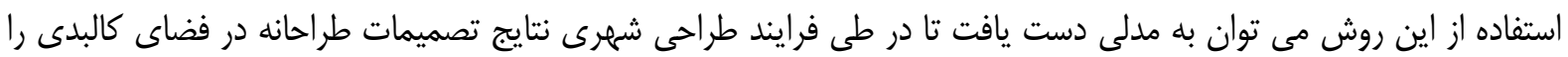

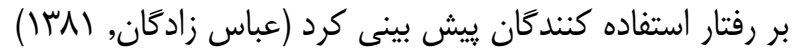

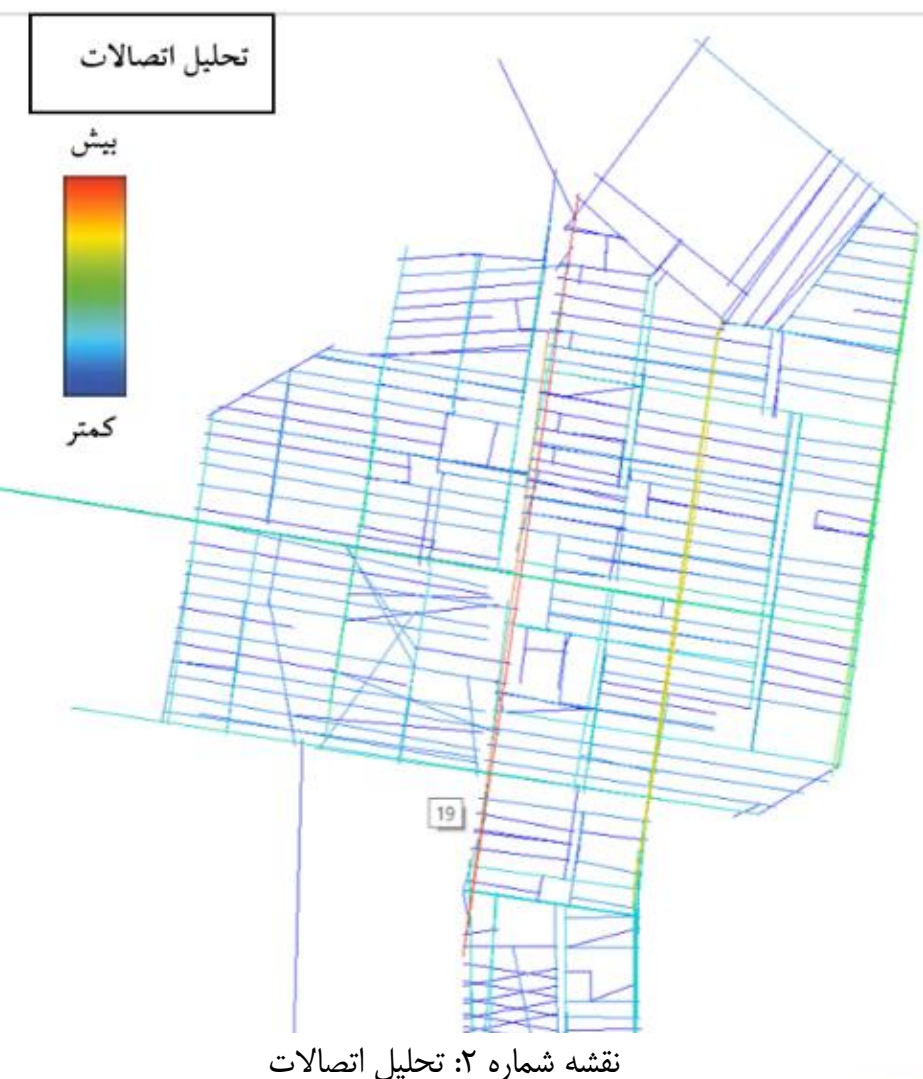

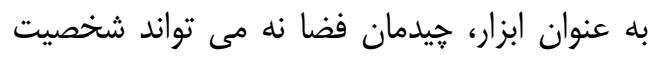

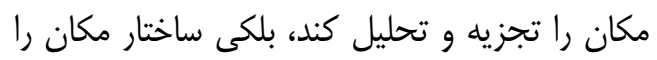

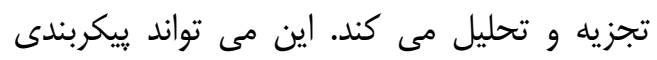

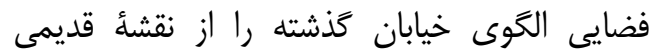
تجزيه و تحليل كند و نتائج را با موقعيت ساختمان

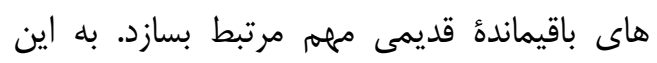

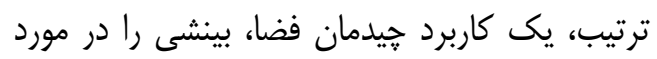
اين كه جرا اين مراكز در كَذشته نسبت به شرايط

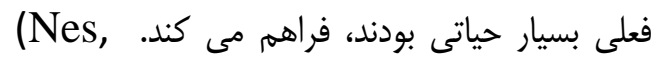
(2014 اين تحليل در نرم افزار DepthmapX انجام

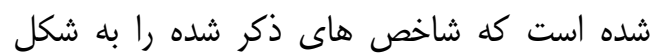

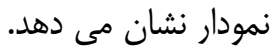
-تحليل اتصال: قرار ملاحظه نقشه، مسير مورد مطالعه (از جهاراهى محبس الى جِهاراهى دوم) 
داراى بيشترين اتصالات ميباشد، اين بدين معنى است كه مسير مورد مطالعه با نقاط مختلف احمدشاه بابا مينه اتصال دارد. تحليل همييوندى: مسير مورد مطالعه داراى بلند ترين درجه همبيوندى بوده و درجه همبيوندى ساير مسير ها در اطراف اين مسير به تدريج كاسته ميشود.

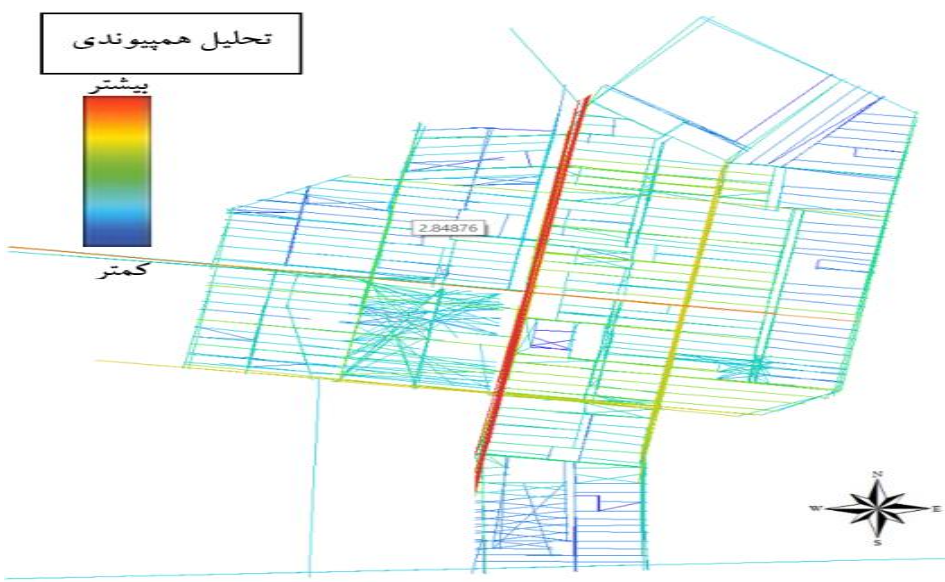
نقشه شماره ": تحليل همبيوندى

تحليل انتخاب:از تحليل انتخاب مسير ديده ميشود كه محور مورد مطالعه داراى بيشترين حد انتخاب نبوده، برعكس سر كه از

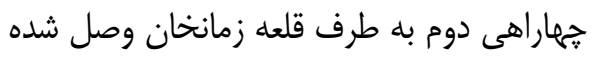

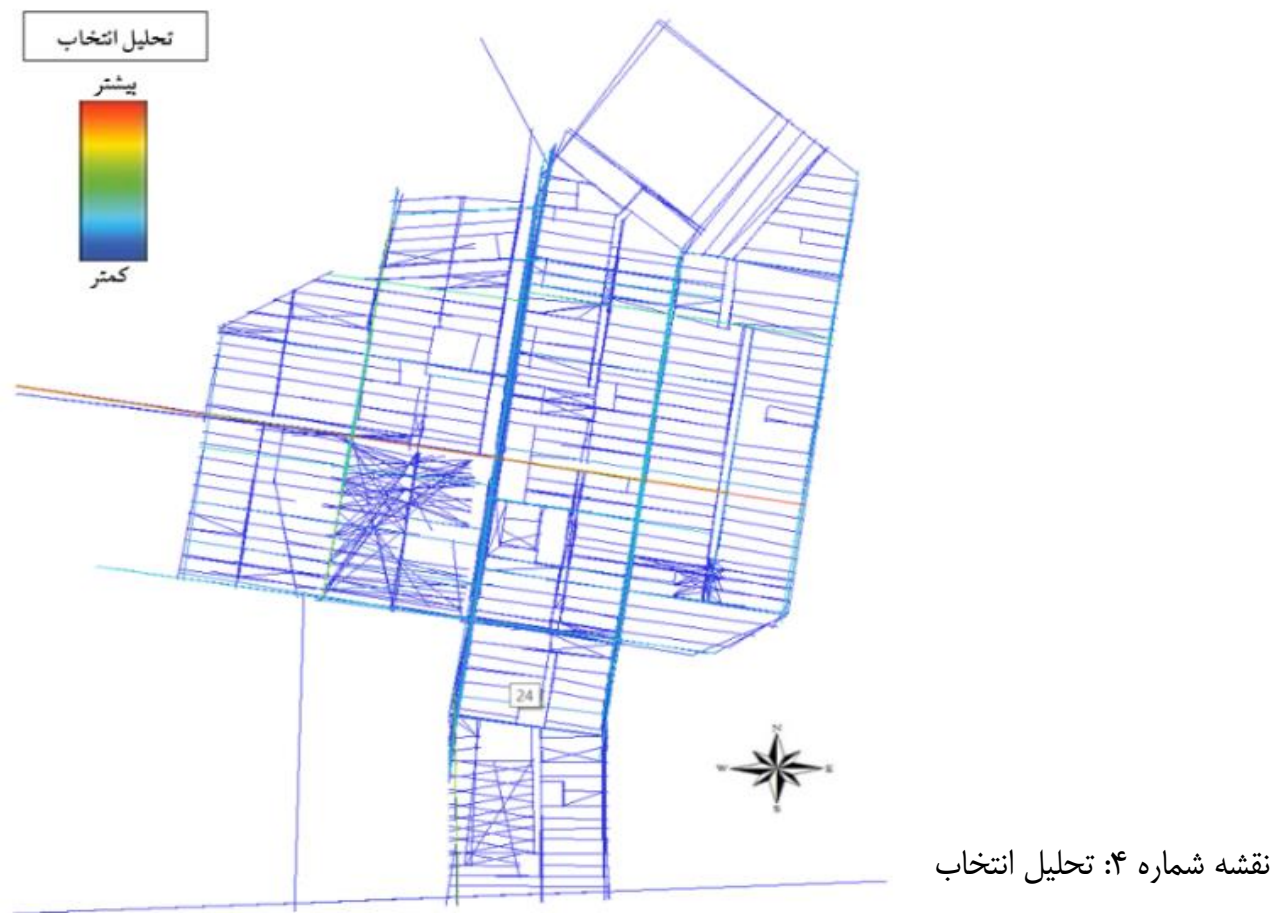




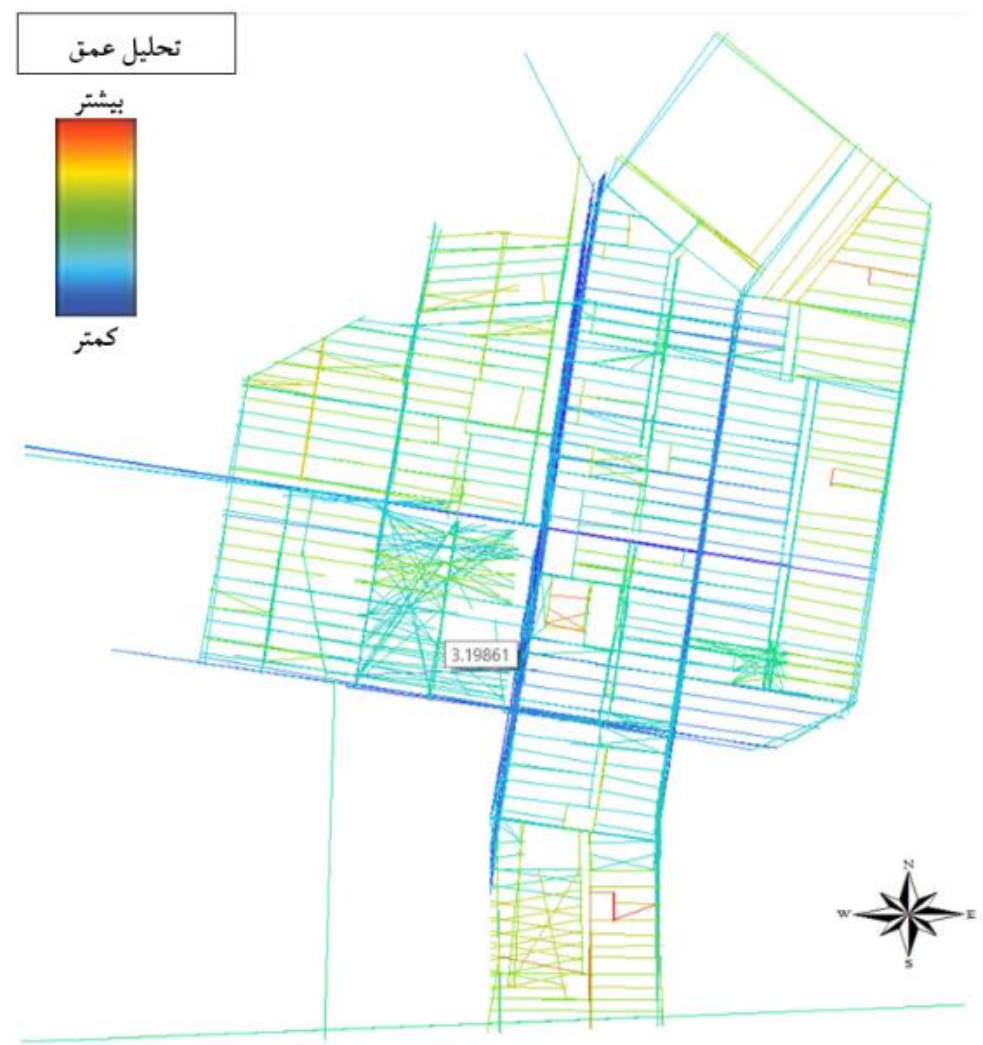

تحليل عمق ميانگين: عمق فضا

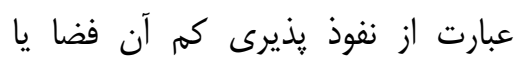

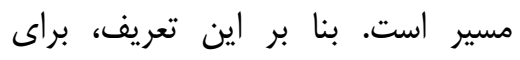
تحقق سرزندگى شهرى عمق اين مسير بايد كم باشد تا توسط افراد زياد مورد

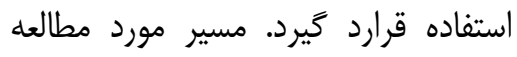

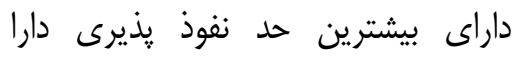
ميباشد.

از تحليل فوق به اين نتيجه مى رسيه كه مسير مورد مطالعه در اتصال و هميبوندى با ديخر قسمت آن تفاوت قابل ملاحظهُ

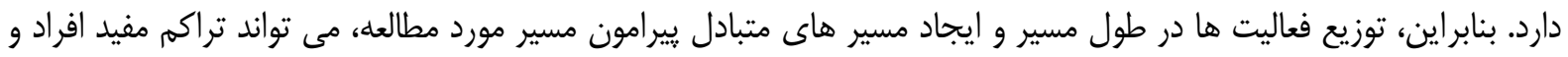
وسايط نقليه را تحقق بدهد

- تحليل توسط اناليز سوات: براى كاربرد اين روش، به تعداد זا يرسش نامئ از افراد داراى آكاهى در بخش هاى

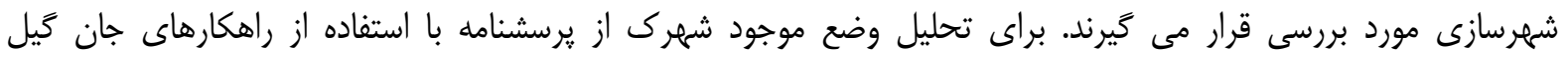
(Westlund, 2018, p. 25)

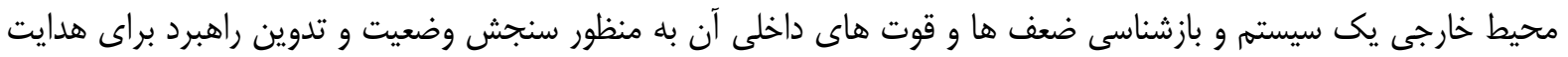

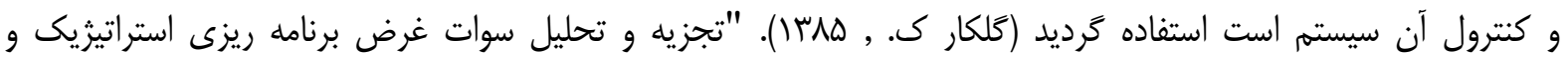
مديريت استراتيزيك استفاده شد. " (The Journal of International Social Research, 2017) در اناليز سوات مولفه هاى ذيل مورد تحليل قرار خرفت.

\begin{tabular}{|c|c|}
\hline نفوذيذيرى و حر كت & \multirow{6}{*}{ عملكردى مولفه } \\
\hline اختلاط كاربرى & \\
\hline همه شمول بودن & \\
\hline كيفيت عرصه همخانى & \\
\hline آسايش اقليمى & \\
\hline ايمنى و امنيت & \\
\hline
\end{tabular}




\begin{tabular}{|c|c|}
\hline سرزندگى و سازَارى قرار كاه هاى رفتارى & \\
\hline انعطاف يذيرى & \\
\hline خوانايى & \multirow{6}{*}{ زيباشناختى مولفه } \\
\hline شخصيت بصرى & \\
\hline حس زمان & \\
\hline غناى حسى & \\
\hline رنى تعلق & \\
\hline آمزندگى & \\
\hline همسازى با طبيعت & \multirow{3}{*}{ زمولفه } \\
\hline انرزى كار آيى & \\
\hline ياكيزگى محيطى & \\
\hline
\end{tabular}

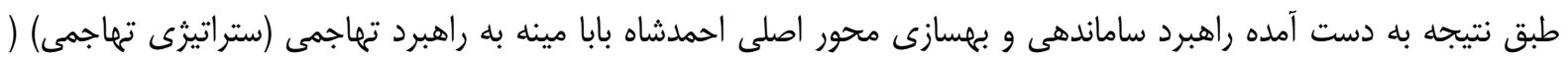

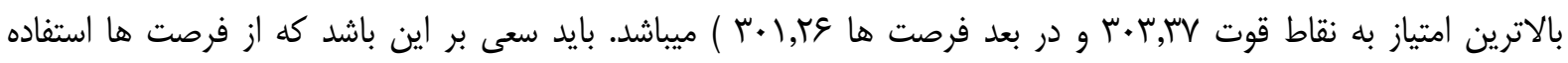
اعظمى صورت گيرد

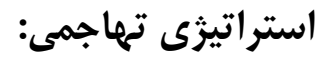

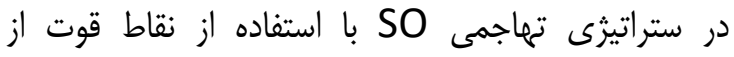

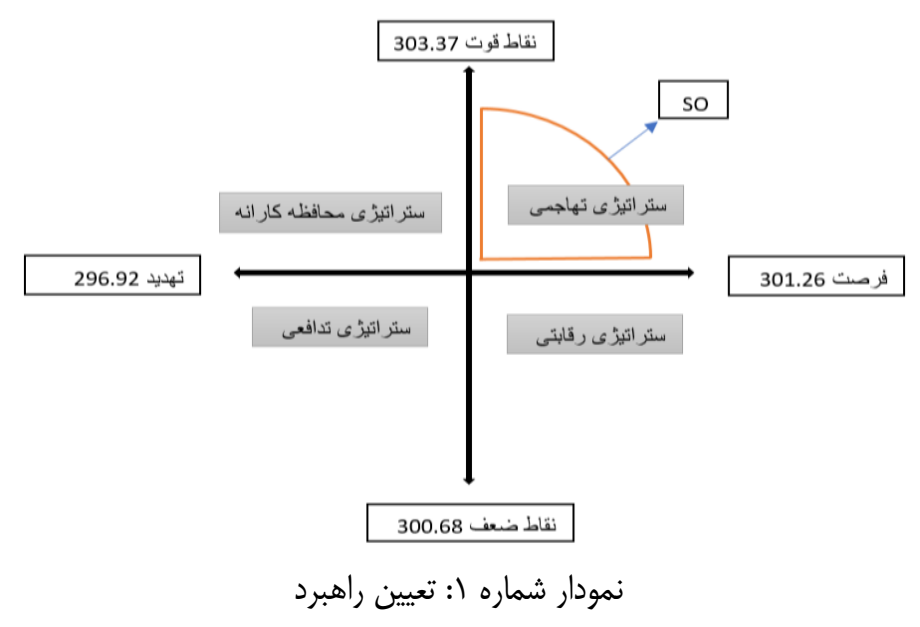

فرصت هاى موجود استفاده صورت ميكيرد:

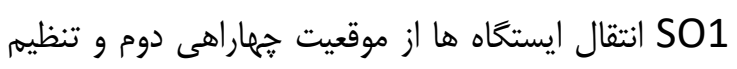
آن در ديخر نقاط شهرك احمدشاه بابا مينه SO2 انتقال و تنظيم دستفروشان در ديخر نقاط شهرى نقاه احمدشاه بابا مينه SO3 توزيع كاربريها در ساختمانهاى جندين طبقه ينه و زمين هاى باير SO4 برطرف نمودن موانع از قبيل انبارهاى اجناس تجارتى از حريم فضاهاى شهرى نمان موان

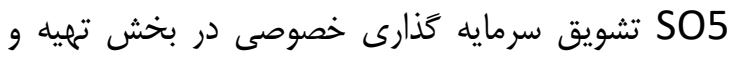

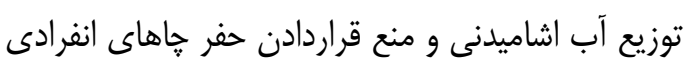
ميك SO6 ايجاد راه هاى بايسكل و تشويق نمودن افراد براى بايسكل رانى كه سبب كاهش وسايط نقليه و تقويت آسايش اقليمى ميكردد SO7 ايجاد التزامات ايمنى از قبيل شير هاى اطفايه و راه هاى اضطرارى در ماركيت هاء

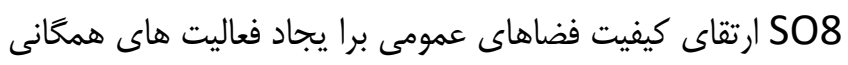


تدوين و تطبيق طرح براى ازدياد نفوذ يذيرى از قبيل ترميم يوشش سرى ها و خيابانها و برطرف نمودن موانع فيزيكى SO10

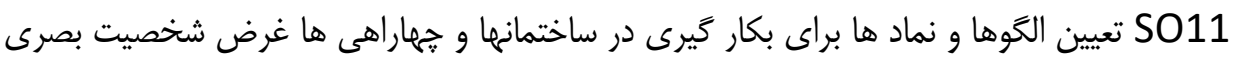

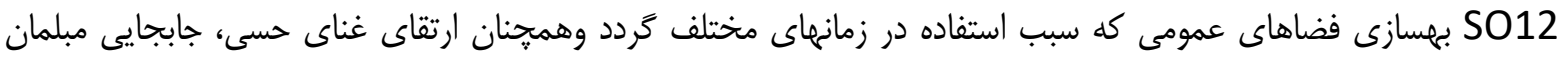

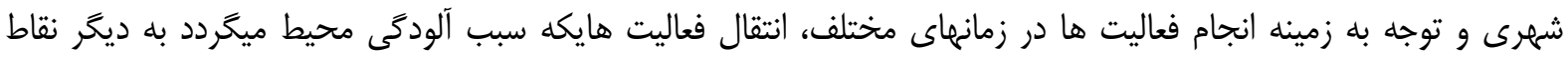

\section{نتيجه كَيرى:}

از نتيجه تحقيق، كه به طور مفصل طى سوات و به طور شماره وار در ستراتيزى تماجمى ذكر گرديده است، معلوم ميشود كه

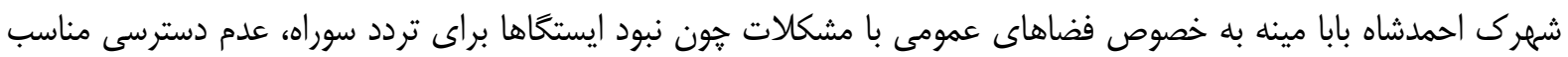

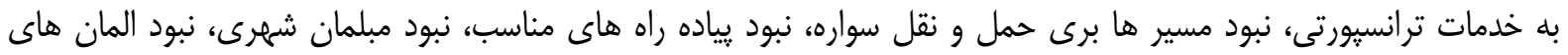

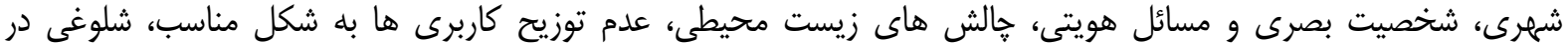

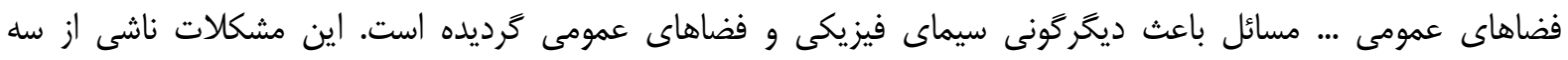
كتَكورى عمده ذيل ميباشد:

1 ـ ضعف مديريتى و عدم فهرم ادارات ذيربط شهردارى در رابطه به مسائل طراحى شهرى: اين امر باعث گرديده تا تا مالكين

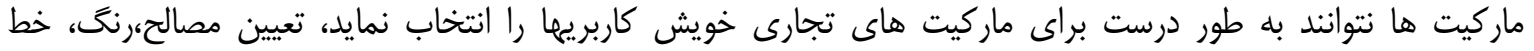

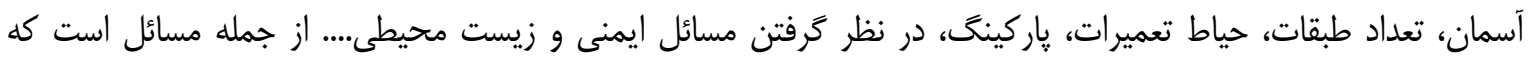

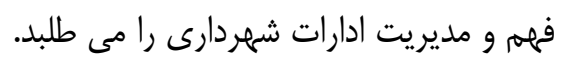

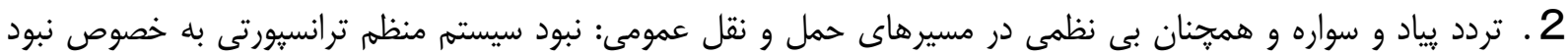

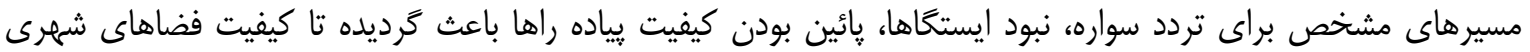

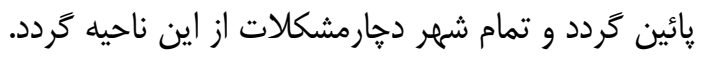

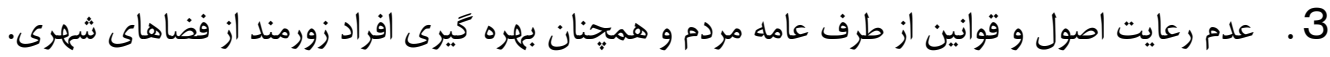

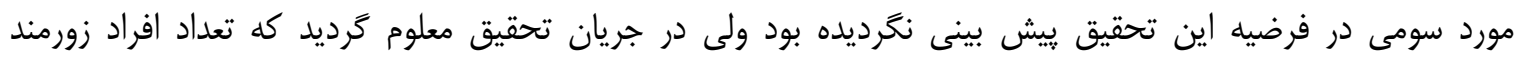

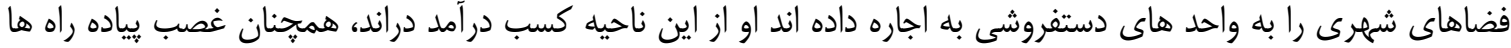

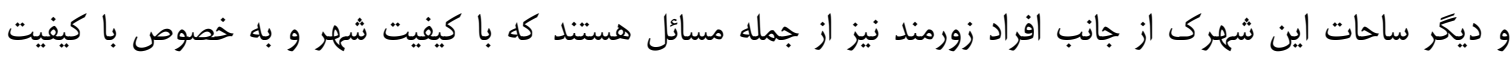
فضاهاى عمومى تاثيرات عمده دارند.

\section{ييشنهادات به اساس ستراتيزى تهاجمى}

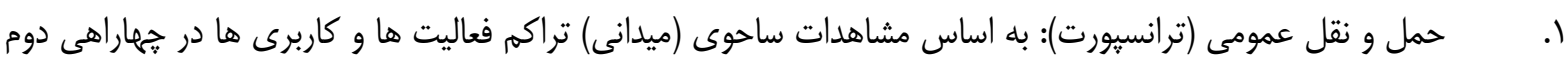

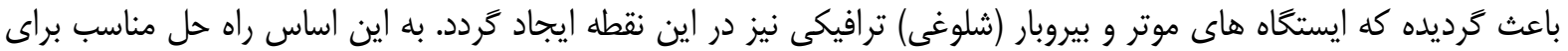
حل معضل ترافيك، توزيع كاربرى ها در ديكر نقاط شهرك و همجنان انتقال ايستخاها ها به ديگر نقاط شهرك ميباشد. يكى ازئ

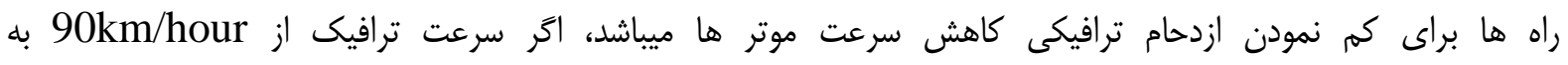

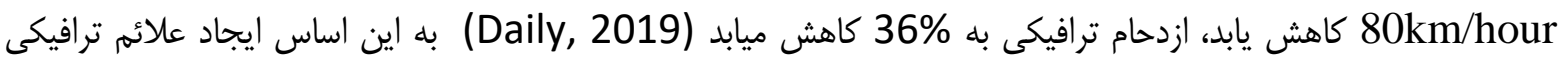

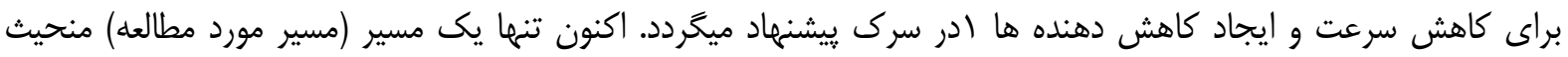

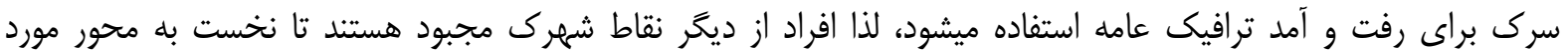

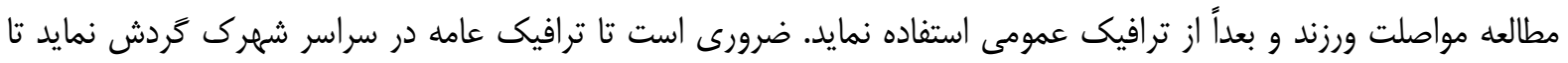

\footnotetext{
${ }^{1}$ Speed Reducer
} 
دسترسى به ترافيك عمومى براى ساير افراد شهرى مناسب باشد. يِشنهاد براى حمل و نقل عمومى قرار ذيل خلاصه كرديده

تعين موقعيت براى ايستخاه موترها: انتقال ايستخاه به دورترين نقطه شهرك تا دورترين نقطه شهرك نيز دسترسى به حمل و

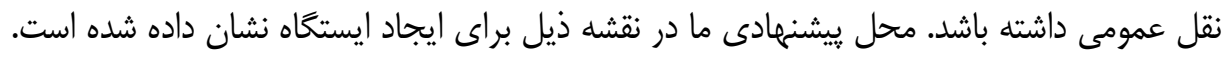

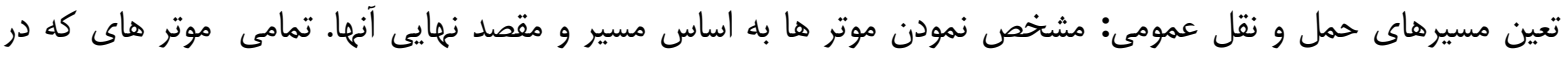

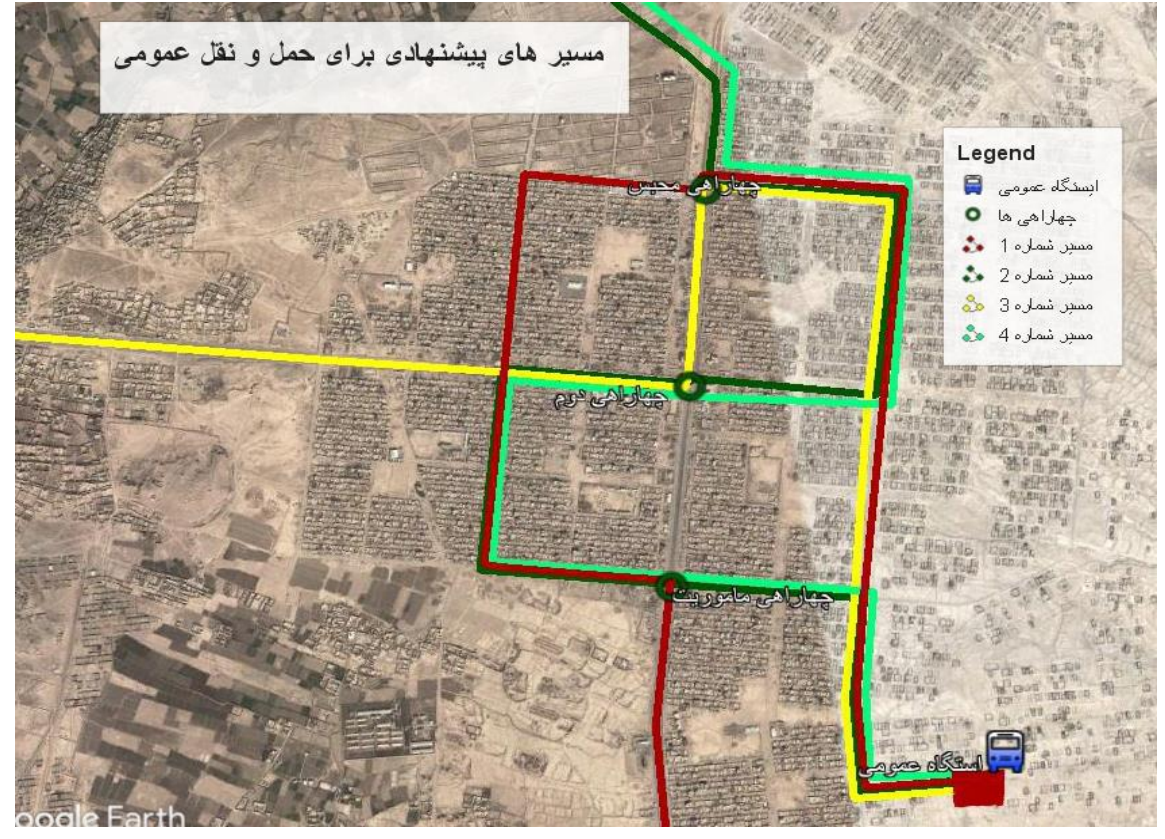

:نقشه شماره \&: مسير هاى ييشنهادى براى حمل و نقل شهرى احمدشاه بابا مينه

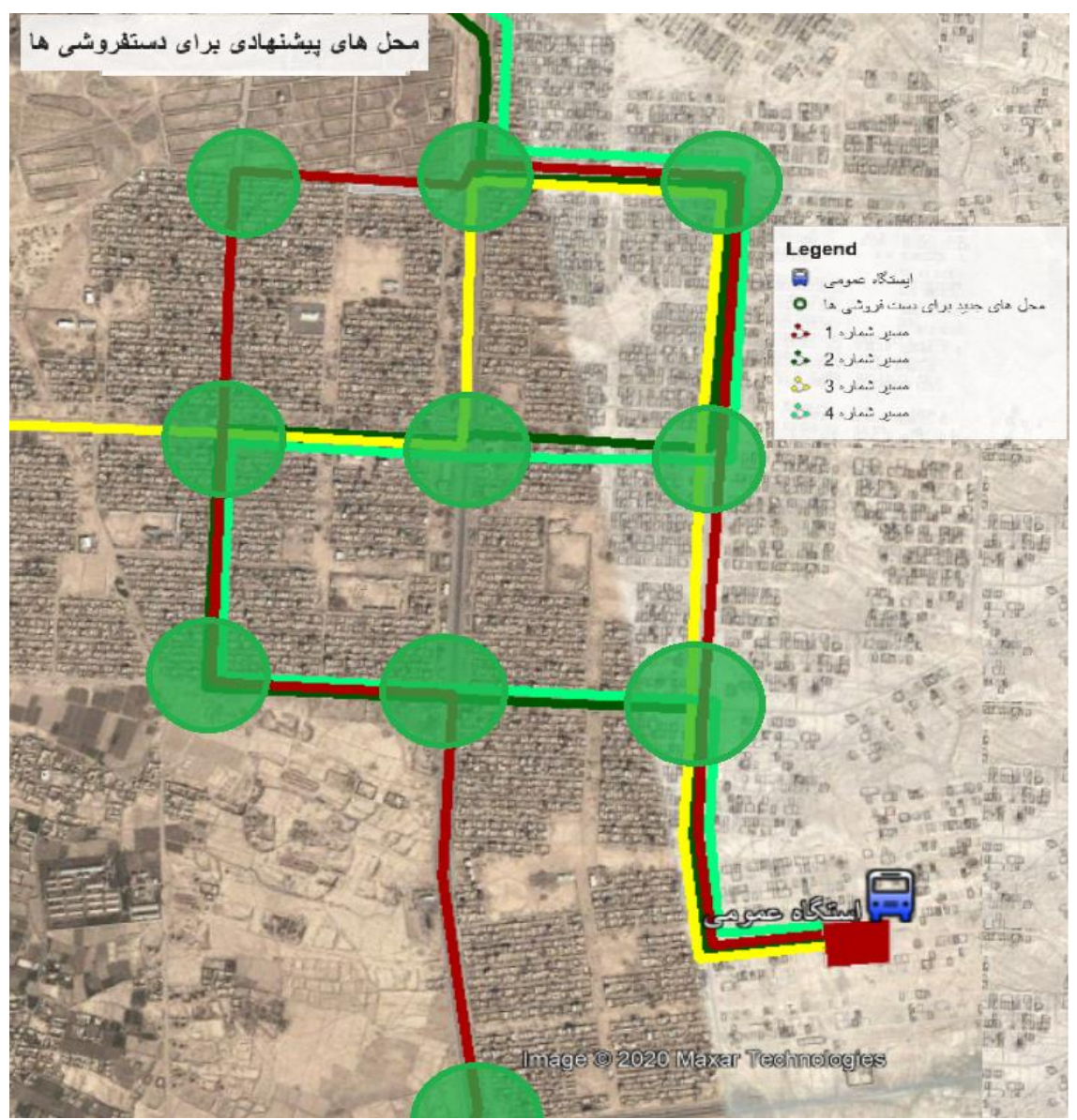

نقشه شماره V: محل هاى ييشنهادى براى دستفروشى ها
حمل و نقل عمومى در شهرك احمدشاه بابا مينه فعاليت مينمايد بايد كتخورى گردد و براى هر كدام

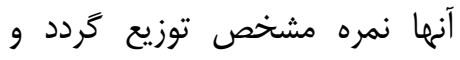

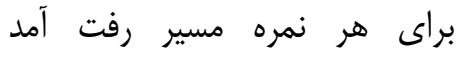
مشخص كردد تعين مسير ها بايد طورى باشد كه امكان دسترسى به كمديه حمل و نقل عمومى براى ساير شهروندان شهرك احمدشاه بابا مينه مهيا گردد و دور ترين فاصله يِاده از مسير حمل و نقل عمومى الى خانه هاى شهروندان از 800 متر تجاوز

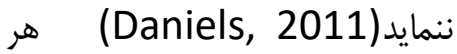
كتخورى (هر موتر داراى نمره مشخص) در مسير مشخص (هرت رفت و

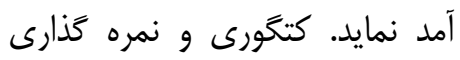
ذيلاً ييشنهاد كرديده است: كتگگورى شماره ا: موترهايكه بين احمدشاه بابا مينه و شهر كابه آ موترهايل بين از طريق مسير جنوبى (باگرامى) در

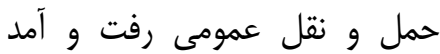
دارد.

كتگگورى شماره rا: موترهايكه بين احمدشاه بابا مينه و شهر كابل آل موترهايكان بين طريق مسير شمالى (خمرى كابل) در حمل و نقل عمومى رفت و آمد آمدابل

$$
\text { دارد. }
$$

كتخورى شماره بّ: موترهايكه بين احمدشاه بابا مينه و شهر كابره طريق مسير قعله زمانخان و شينه در حمل و نقل عمومى رفت و آمد دارد. كتخورى شماره عا: موترهايكه بين رفي 
احمدشاه بابا مينه و يل جرخى در حمل و نقل عمومى رفت و آمد دارد.

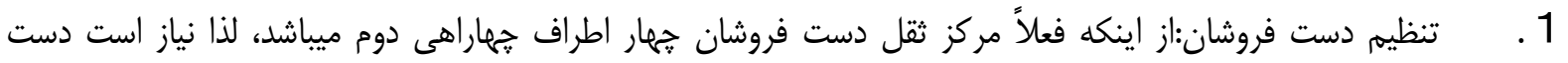

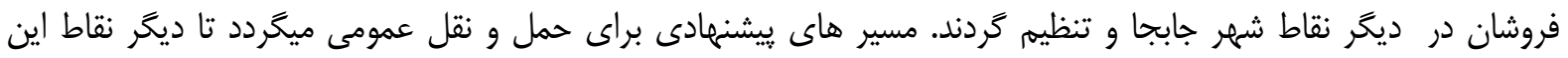

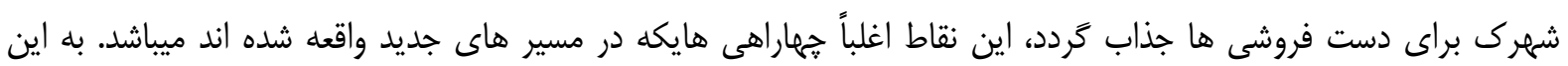

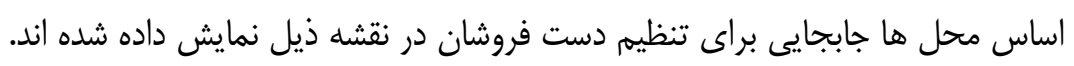

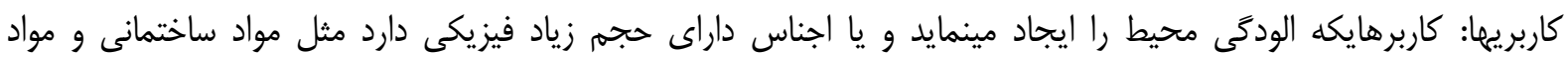

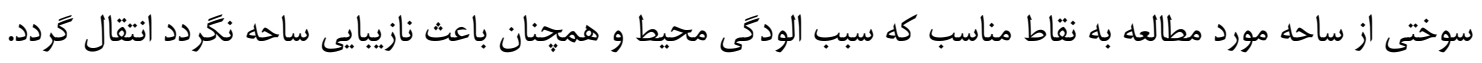

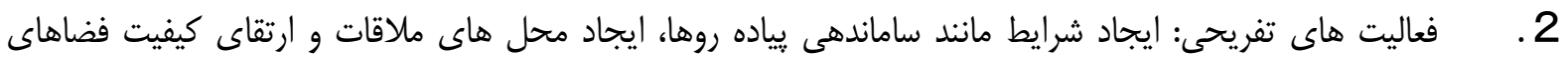

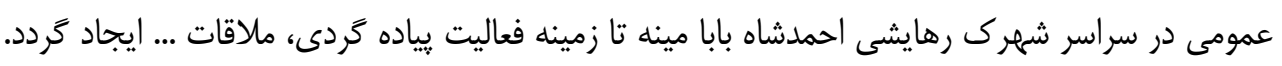

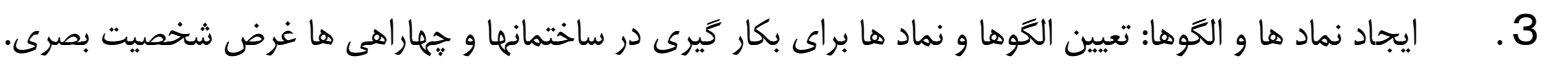

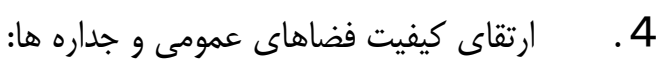

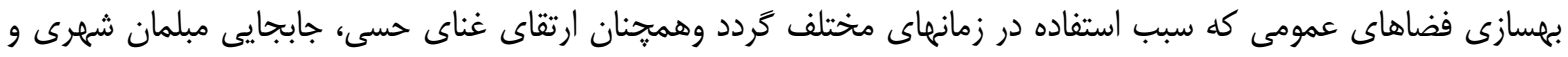

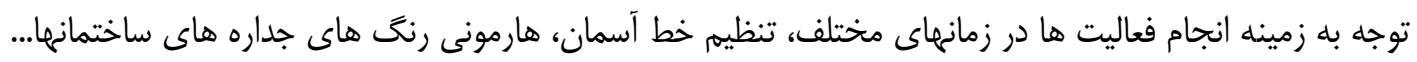

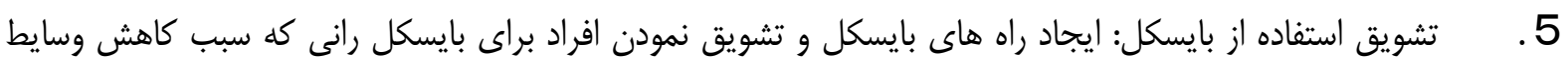
نقليه و تقويت آسايش اقليمى ميخر دد

\section{6 . 6}

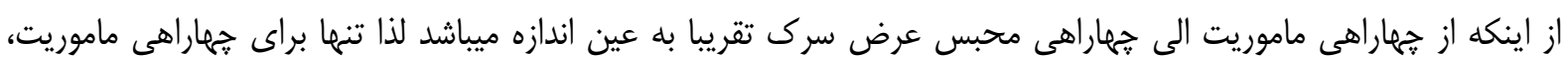

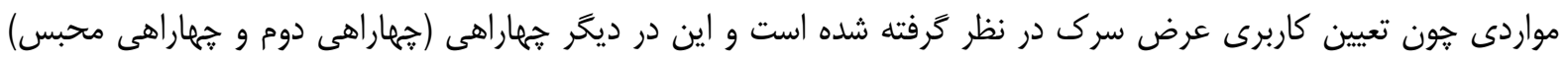

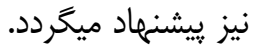

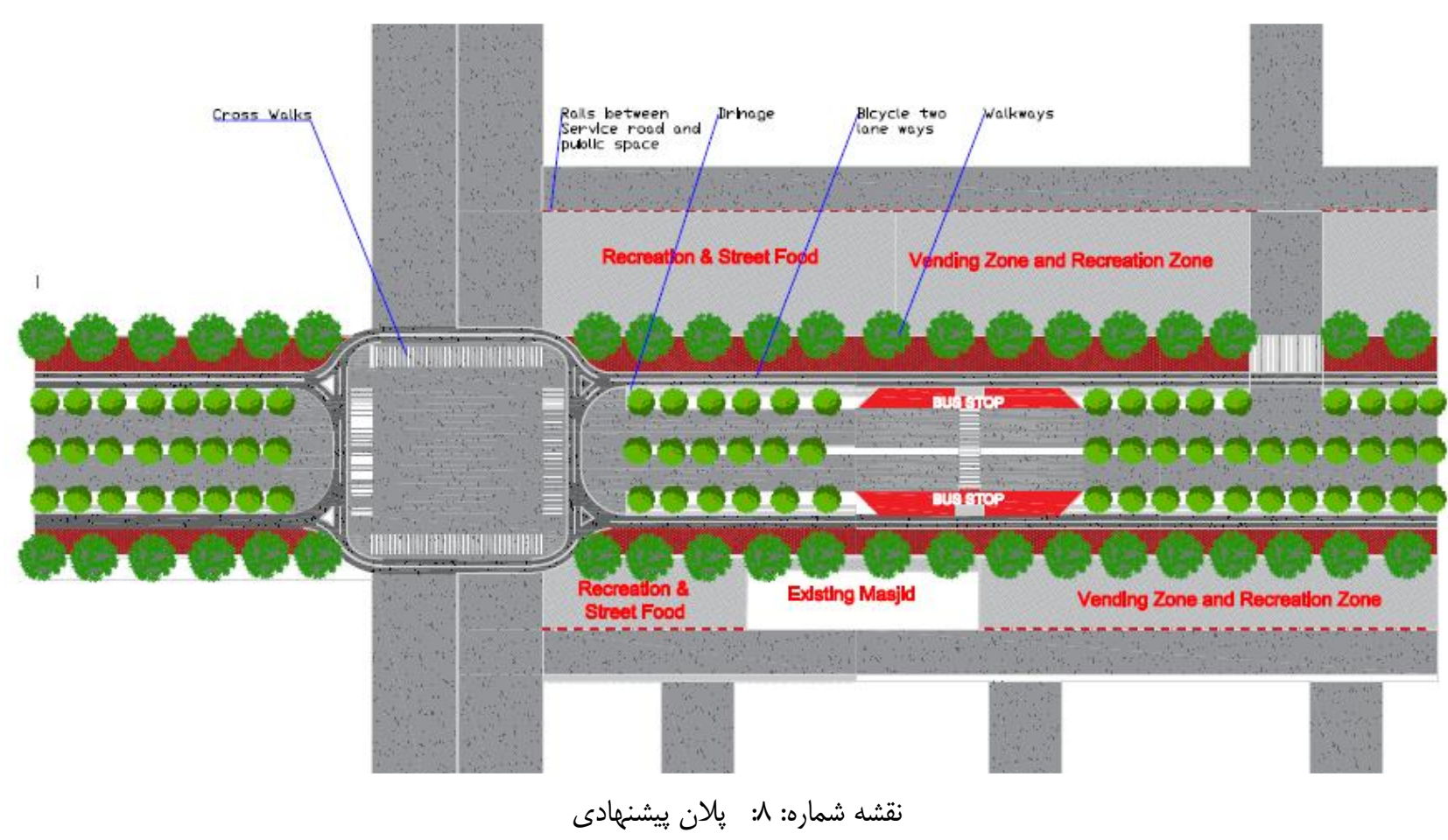




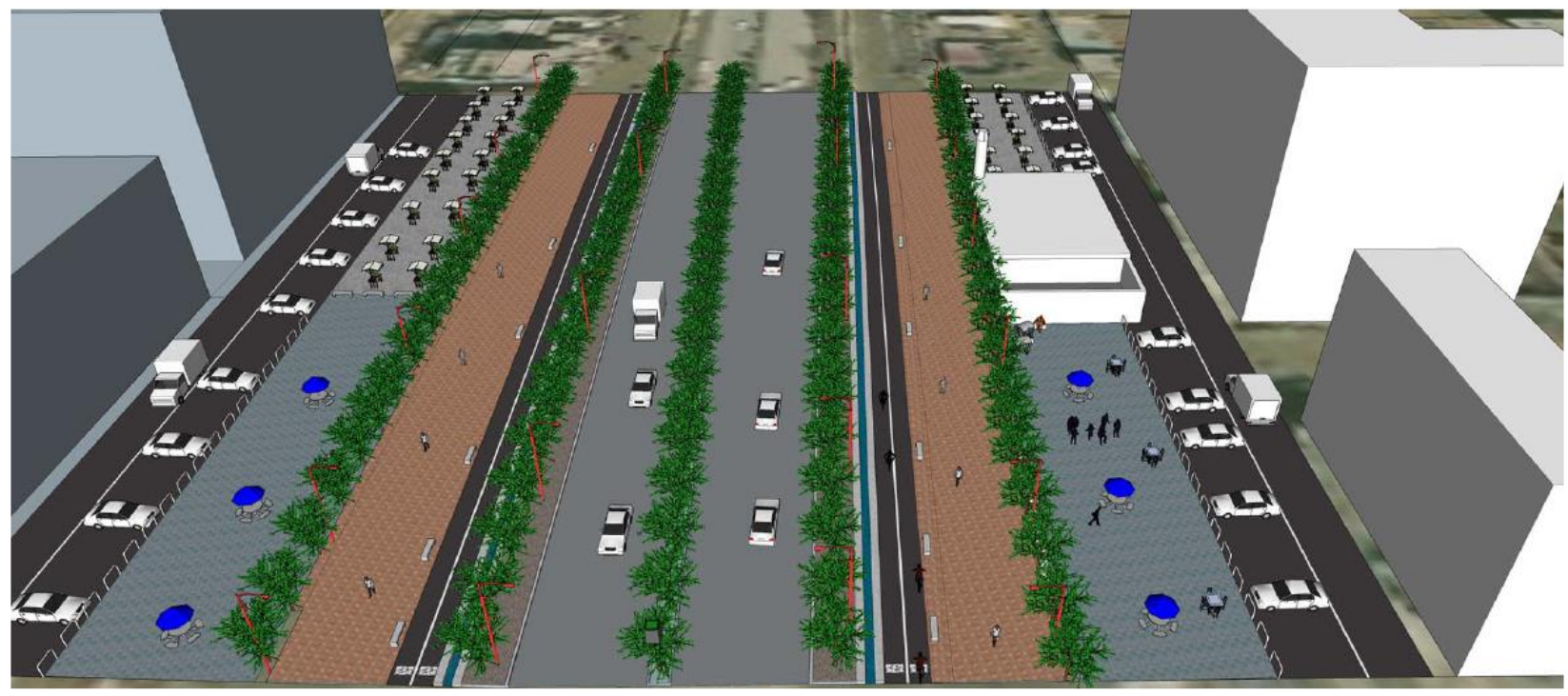

نقشه شماره 9: نقشه ييشنهادى سه بعدى

7 7 حريم ملكيت خصوصى: ارتفاع زياد طبقه اولى ملكيت خصوصى باعث اين گرديده است كه به زمين فضاى

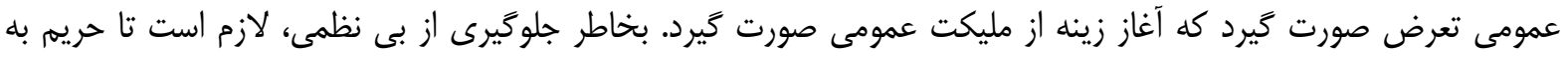
عرض ه,ا از ملكيت عمومى براى دسترسى به طبقه اول در نظر گَرفته شود تا تمام دسترسى تمام ماركيت ها كه در مسير مورد

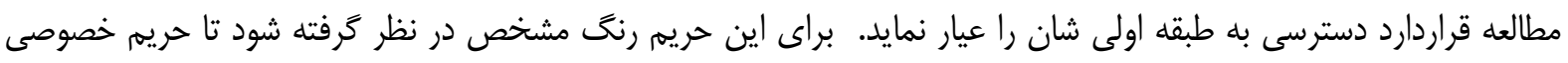
از حريم فضاى عمومى تفكيك گردد و ملكيت خصوصى نتواند به ملكيت عمومى تعرض نمايد.

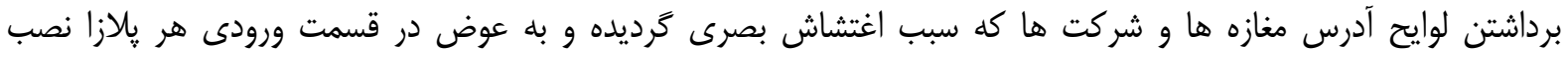
نمودن لوحه عمومى براى ادرس هاى تمام واحدهاى تجارتى كه در آن فعاليت مينمايند

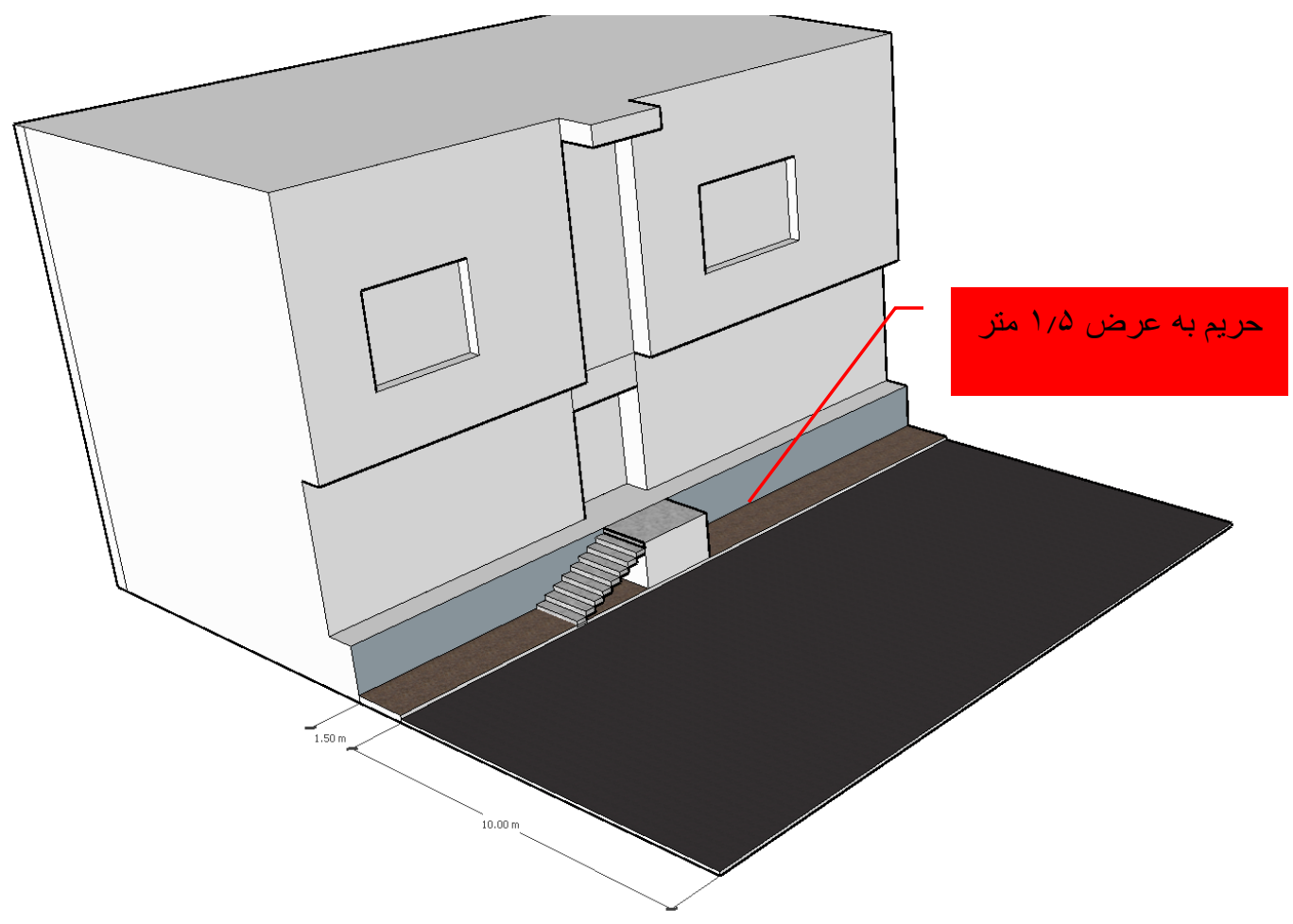

نقشه شماره • 1 : تعيين حريم براى ملكيت خصوصى 
8 8. تنظيم خط آسمان: از اينكه ديده ميشود كه خط آسمان داراى ريتم منظم نبوده. اختلاف طبقات،

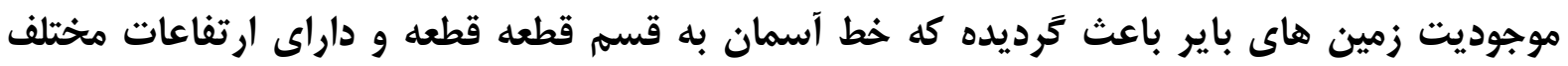

با توجه به وضعيت كنونى، ميتوان براى تنظيم خط آسمان از گزينه هاى ذيل استفاده نمود:

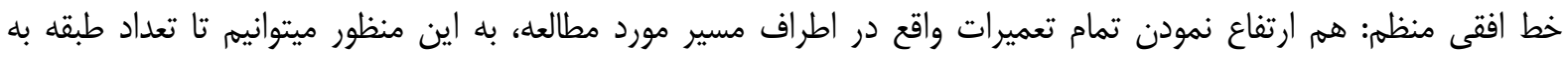

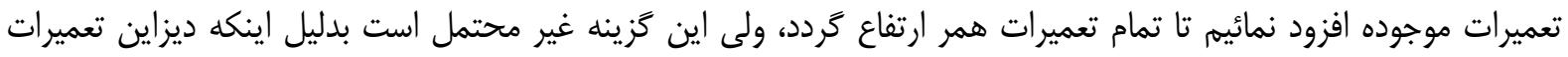

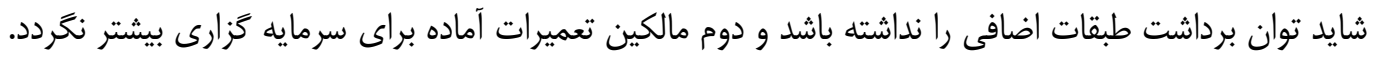

$$
\text { منابع فارسى }
$$

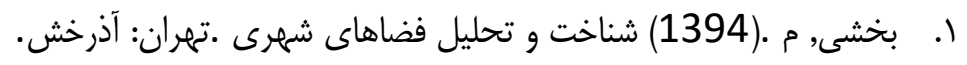

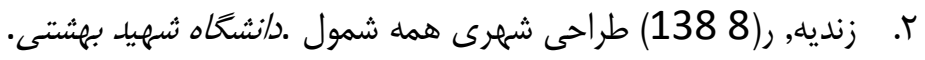

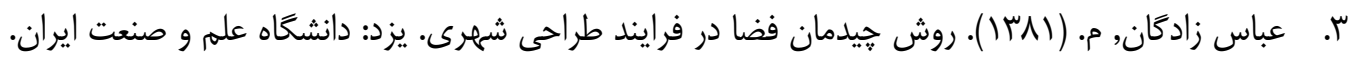

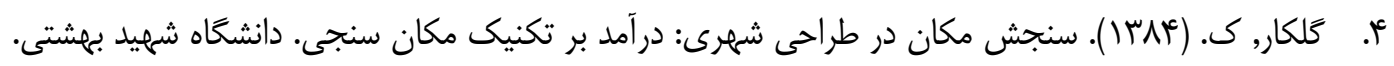

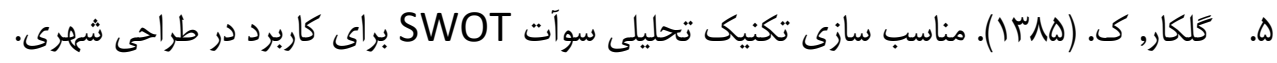

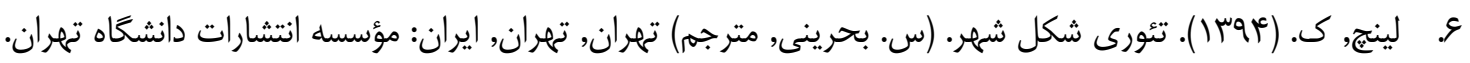

1. Daily, U. M. (2019), August Urban Mobility Daily. Retrieved from https://urbanmobilitydaily.com/: reduce-traffic-jams-in-our-cities/ https://urbanmobilitydaily.com/how-to-

2. Daniels, R. (2011). Explaining walking distance to public transport: The dominance of public transport supply. Journal of Transport and Land Use.

3. Groundwater Contamination. (n.d.). Retrieved from Groundwater Foundation: https://www.groundwater.org/get-informed/groundwater/contamination.html

4. Nes, A. V. (2014). Space Syntax in Theory and Practice. Delft, Netherlands: Springer International Publishing.

5. The Journal of International Social Research. (2017). SWOT Analysis: Atheoretical Review. The Journal of International Research.

6. Westlund, K. (2018). Method for studying Public Spaces' impact on their Life. Lulea University of Technology. 